\title{
Morphometric Analysis of Infraorbital Foramen and Infraorbital Canal in Human Feotuses
}

\author{
Análisis Morfométrico del Foramen Infraorbitario \\ y Canal Infraorbitario en Fetos Humanos
}

"Farah Ghaus \& **Faruqi N. A.

FARAH, G. \& FARUQI, N. A. Morphometric analysis of infraorbital foramen and infraorbital canal in human feotuses. Int. J. Morphol., 26(2):289-292, 2008.

SUMMARY: Literature regarding analysis of infraorbital foramen and canal exists in adult but it is scanty in foetuses.Morphometric measurements were performed in sixty maxillae dissected out from thirty human foetuses. The latter were divided into five groups on the basis of age i.e. groups I(<17 weeks IUL),II (17-20 weeks IUL), III (21-25 weeks IUL),IV (26-30 weeks IUL) and V (>30 weeks IUL).Four parameters considered were length of infraorbital foramen and canal and width of anterior and posterior ends of infraorbital foramen. Range of measurements between the smallest foetal group to largest foetal group for length of infraorbital foramen and canal and width at the anterior and posterior ends of infraorbital foramen were $4.01 \mathrm{~mm}$ to $6.00 \mathrm{~mm}, 0.67 \mathrm{~mm}$ to $2.60 \mathrm{~mm}, 0.64 \mathrm{~mm}$ to $1.65 \mathrm{~mm}$ and $1.39 \mathrm{~mm}$ to $3.01 \mathrm{~mm}$, respectively.The shape of the infraorbital foramen is maintained in most of the groups.Correlation coefficient analysis between measurements of lengths and aging foetuses is indicative of variable osteoblastic and osteoclastic activities.Enhanced osteoblastic activity seems to be an important phenomenon in postnatal life.

KEY WORDS: Infraorbital foramen; Infraorbital canal; Human foetuses; Morphology; Maxilla.

\section{INTRODUCTION}

Infraorbital foramen and canal are important landmarks in the floor of orbit for the passage of infraorbital nerve. Infraorbital nerve blocking through infraorbital canal is used to anaesthetize the lower eyelid,upper lip, lateral nose, upper teeth and related gingivae. A detailed knowledge of anatomic morphometry of this area is necessary for surgeons while performing maxillofacial surgery.

Kazkayasi et al. (2003) performed a study on ten cadaver heads (20 sides) to find out the variations of infraorbital canal which must be taken into account by the surgeons to increase the surgical success. Detailed studies on infraorbital foramen and canal were undertaken in different races from time to time, e.g., in Koreans (Hwang \& Baik, 1999; Lee et al., 2006), Brazilians (Elias et al., 2004) and Egyptians (Hindy \& Abdel-Raouf, 1993). Aforementioned references belonged to adult anatomy. Recently the various invasive and non invasive approaches aimed at correction of different foetal defects had led to the emergence of a highly promising superspeciality of foetal therapy. Foetal repair of the congenital diaphragmatic hernia was technically made possible by Soper et al. (1984).

McKinstry(1987) for the first time established correlation between location of the anterior end of infraorbital canal and cleft palate. Such correlation has further enhanced the scope of study on foetal anatomy. Unfortunately the detailed morphometric informations on foetal anatomy in general and infraorbital foramen and canal during intrauterine life specifically are scanty in literature.

The aim of the present study is to find out accurate foetal anatomy of infraorbital foramen and canal and establish the exact pattern of their growth during intrauterine life, which might reflect informations about their postnatal anatomy both normal and abnormal.

\footnotetext{
* Senior Resident, MBBS, MD.

${ }^{* *}$ Professor, MBBS, MS.

Department of Anatomy J. N. Medical College, Aligarh Muslim University, Aligarh, India.
} 


\section{MATERIAL AND METHOD}

Sixty dissected and isolated maxillae were used for the study. Ages of foetuses ranged from 16 weeks to 34 weeks of intrauterine life (IUL). Foetuses were divided into five groups according to age (Table I). Periosteum and soft tissue adherent to the infraorbital foramen and infraorbital canal were carefully removed under dissecting microscope. Infraorbital foramen was defined as elongated depression with well demarcated margins in the orbital surface of body of maxilla. Infraorbital canal was recognized as bony tunnel connecting the infraorbital foramen with infraorbital foramen (Fig. 1).

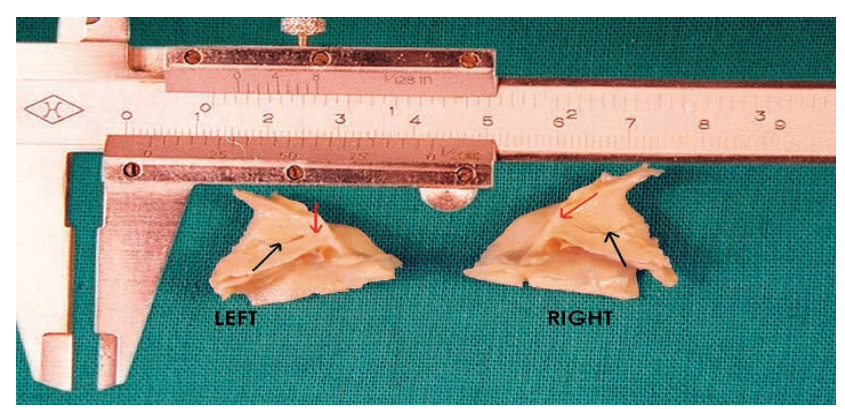

Fig. 1. Right and left maxillae showing infraorbital foramen and canal in the orbital surface.

Length of infraorbital foramen and canal and width of infraorbital foramen at the extremes were measured under dissecting microscope by using Vernier callipers (Tables II, IV, VI and VII). The growth between adjacent groups were statistically analysed by using Student's ' $t$ ' test. The correlation between the growth of infraorbital foramen and canal and age of foetuses was established by correlation coefficient test.

\section{RESULTS}

Both infraorbital foramen and canal showed variable rates in the growth of lengths with the increase in foetal age (Tables II and IV). Correlation coefficient study determined that some association did exist between length of infraorbital foramen and canal on one hand and age of the foetus on the other hand (Tables III and V).

Table I. Groups of human foetuses.
Spurt of growth was noticed in groups III and IV foetuses for infraorbital foramen (Table II) and groups II and IV foetuses for infraorbital canal (Table IV). This clearly indicates that in group II foetuses, osteoblastic activity has an upper hand. In group III foetuses, osteoclastic activity has an upper hand. In group IV foetuses, both osteoblastic and osteoclastic activities balance each other. Posterior end of infraorbital foramen is always wider (almost double) than the anterior end except in group IV where measurements of the two equal each other (Tables VI and VII).This is indicative of little morphological change in the foramen during intrauterine life.

\section{DISCUSSION}

Report of Kazkayasi et al. on infraorbital foramen and canal in adult cadavers presented a very interesting phenomenon. They found the presence of a complete infraorbital canal only (without foramen ) in 50\% cases and both foramen and canal in rest of the $50 \%$ cadavers. The former condition was not noticed in any sample in our study. That means the bridging of the infraorbital foramen to convert it into canal is an important feature after birth. Usually, scientists have measured the length of foramen and canal together.

Hwang \& Baik measured the combined length of infraorbital foramen and canal in adult skulls and found it to be approximately $26 \mathrm{~mm}$. Hindy \& Abdel-Raouf on the other hand reported the aforementioned length to be $28 \mathrm{~mm}$. Racial factor may be the reason for the difference. Latter, scientists noticed presence of infraorbital foramen along with canal in $60 \%$ cases only. Wolff (1954) mentioned the ratio of infraorbital foramen and canal to be 1:1 in adults. In our finding in human foetuses, the infraorbital foramen was approximately $4 \mathrm{~mm}$ but the canal was little more than $0.5 \mathrm{~mm}$ in group I foetuses (Tables II and IV). At the end of intrauterine life i.e. group V foetuses, there was only one and half times increase in the length of infraorbital foramen (Table II) but nearly 4 times increase in the length of canal (Table IV). This is due to, as expected, continuous bridging of foramen and increase in the length of canal on the cost of foramen. This process continues even after birth so that the length of canal equals the length of foramen or completely replaces it as the case may be.

\begin{tabular}{clccccc}
\hline Groups & Age $(\mathbf{w k s})$ & $\mathbf{N}^{\circ}$ of males & $\mathbf{N}^{\circ}$ of maxillae & $\mathbf{N}^{\circ}$ of females & $\mathbf{N}^{\circ}$ of maxillae & Total $^{\circ}$ of maxillae \\
\hline I & $<17$ & 6 & 12 & 0 & 0 & 12 \\
II & $17-20$ & 8 & 16 & 0 & 0 & 16 \\
III & $21-25$ & 7 & 14 & 1 & 2 & 16 \\
IV & $26-30$ & 3 & 6 & 2 & 4 & 10 \\
V & $>30$ & 2 & 4 & 1 & 2 & 6 \\
\hline
\end{tabular}


FARAH, G. \& FARUQI, N. A. Morphometric analysis of infraorbital foramen and infraorbital canal in human feotuses. Int. J. Morphol., 26(2):289-292, 2008.

Table II. Length of infraorbital foramen in the orbital floor in human foetuses.

\begin{tabular}{ccccc}
\hline Groups & $\mathbf{N}^{\mathbf{0}}$ of cases & Mean $\pm \mathbf{S D}(\mathbf{m m})$ & \% change & P value \\
\hline I & 12 & $4.01 \pm 0.68$ & - & \\
II & 16 & $3.90 \pm 0.69$ & -3 & $<0.2$ \\
III & 16 & $4.80 \pm 1.37$ & +23 & $<0.002$ \\
IV & 10 & $6.12 \pm 2.00$ & +28 & $<0.02$ \\
V & 6 & $6.00 \pm 1.65$ & -2 & $<0.5$ \\
\hline
\end{tabular}

Table III. Correlation coefficient between length of infraorbital foramen and foetal age.

\begin{tabular}{|c|c|c|c|c|c|}
\hline \multicolumn{2}{|c|}{ Foetal age } & \multirow{2}{*}{$\begin{array}{l}\text { Mean of age } \\
\text { (weeks) }\end{array}$} & \multirow{2}{*}{$\begin{array}{l}\text { Mean of foramen } \\
\text { length }(\mathrm{mm})\end{array}$} & \multirow[t]{2}{*}{$\mathrm{N}^{\circ}$ of variables } & \multirow{2}{*}{$\begin{array}{c}\text { Correlation } \\
\text { coefficient } \\
(-)\end{array}$} \\
\hline Groups & Range(weeks) & & & & \\
\hline I & $<17$ & 17 & 3.09 & 12 & 0.7 \\
\hline II & $17-20$ & 19 & 3.9 & 16 & 0.2 \\
\hline III & $21-25$ & 22 & 4.8 & 16 & 0.4 \\
\hline IV & $26-30$ & 28 & 6.16 & 10 & 0.1 \\
\hline $\mathbf{V}$ & $>30$ & 32 & 6 & 6 & 0.4 \\
\hline
\end{tabular}

Table IV. Length of infraorbital canal in the orbital floor in human foetuses.

\begin{tabular}{ccccc}
\hline Groups & $\mathbf{N}^{\mathbf{0}}$ of cases & Mean $\pm \mathbf{S D}(\mathbf{m m})$ & \% change & P value \\
\hline I & 12 & $0.67 \pm 0.07$ & - & - \\
II & 16 & $1.07 \pm 0.43$ & +60 & $<0.005$ \\
III & 16 & $1.27 \pm 0.50$ & +19 & $<0.1$ \\
IV & 10 & $3.20 \pm 2.30$ & +152 & $<0.02$ \\
V & 6 & $2.60 \pm 0.68$ & -19 & $<0.2$ \\
\hline
\end{tabular}

Table V. Correlation coefficient between length of infraorbital canal and foetal age.

\begin{tabular}{lccccc}
\hline Foetal age & $\begin{array}{c}\text { Mean of age } \\
(\mathbf{w} \text { eks) }\end{array}$ & $\begin{array}{c}\text { Mean of canal } \\
\text { length }(\mathbf{~ m m})\end{array}$ & $\mathbf{N}^{\mathbf{0}}$ of variables & $\begin{array}{c}\text { Correlation } \\
\text { coefficient (_) }\end{array}$ \\
\hline Groups & Range(weeks) & 17 & 0.67 & 12 & -0.4 \\
II & $<17$ & 19 & 1.07 & 16 & 0.006 \\
III & $17-20$ & 22 & 1.27 & 16 & -0.4 \\
IV & $21-25$ & 28 & 3.2 & 10 & 0.3 \\
V & $26-30$ & 32 & 2.6 & 6 & 0.3 \\
\hline
\end{tabular}

Table VI. Width of anterior end of infraorbital foramen in human foetuses.

\begin{tabular}{ccccc}
\hline Groups & $\mathbf{N}^{\mathbf{0}}$ of cases & Mean $\pm \mathbf{S D}(\mathbf{m m})$ & \% change & P value \\
\hline I & 12 & $0.61 \pm 0.15$ & - & - \\
II & 16 & $0.74 \pm 0.31$ & +21 & $<0.05$ \\
III & 16 & $1.30 \pm 0.55$ & +76 & $<0.001$ \\
IV & 10 & $2.77 \pm 0.45$ & +113 & $<0.8$ \\
V & 6 & $1.65 \pm 0.31$ & -40 & $<0.001$ \\
\hline
\end{tabular}


FARAH, G. \& FARUQI, N. A. Morphometric analysis of infraorbital foramen and infraorbital canal in human feotuses. Int. J. Morphol., 26(2):289-292, 2008.

Table VII. Width of posterior end of infraorbital foramen in human foetuses.

\begin{tabular}{ccccc}
\hline Groups & $\mathbf{N}^{\mathbf{0}}$ of cases & Mean $\pm \mathbf{S D}(\mathbf{m m})$ & \% change & P value \\
I & 12 & $1.39 \pm 0.31$ & - & - \\
II & 16 & $1.44 \pm 0.30$ & +4 & $<0.2$ \\
III & 16 & $2.01 \pm 0.51$ & +40 & $<0.001$ \\
IV & 10 & $2.65 \pm 0.32$ & +32 & $<0.001$ \\
V & 6 & $3.01 \pm 0.41$ & +14 & $<0.02$ \\
\hline
\end{tabular}

FARAH, G. \& FARUQI, N. A. Análisis morfométrico del foramen infraorbitario y canal infraorbitario en fetos humanos. Int. J. Morphol., 26(2):289-292, 2008.

RESUMEN: Existe literatura en relación con el análisis de foramen y canal infraorbitarios en adultos pero es escasa en fetos. Se realizaron mediciones morfométricas en 60 maxilares disecados de 30 fetos humanos. Los fetos fueron divididos en cinco grupos en función de la edad, es decir los grupos I (<17 semana VIU), II (17-20 semanas VIU), III (21-25 semanas VIU), IV (26-30 semanas VIU) y V (> 30 semanas VIU). Fueron considerados cuatro parámetros : longitudes del foramen y canal infraorbitario y anchos anterior y posterior de los extremos del foramen infraorbitario. El rango de las mediciones entre el grupo de fetos más pequeño al grupo más grande tanto de las longitudes del foramen y canal infraorbitario como los anchos de los extremos en la parte anterior y posterior del foramen infraorbitario fueron: $4.01 \mathrm{~mm}$ a $6.00 \mathrm{~mm}, 0.67 \mathrm{~mm}$ a $2.60 \mathrm{~mm}, 0.64 \mathrm{~mm}$ a $1.65 \mathrm{~mm}$ y $1.39 \mathrm{~mm}$ a $3.01 \mathrm{~mm}$, respectivamente. La forma del foramen infraorbitario se mantuvo en la mayoría de los grupos. El análisis del coeficiente de correlación entre las mediciones de longitudes y edades de los fetos, es indicativo de las variables de actividades osteoblástica y osteoclástica. El aumento de la actividad osteoblástica parece ser un fenómeno importante en la vida postnatal.

PALABRAS CLAVE: Foramen infraorbital; Canal infraorbital; Fetos humanos; Morfología; Maxilar.

\section{REFERENCES}

Elias, M. G.; Silva, R. B.; Pimentel, M. L.; Cardoso, V. T. S..; Rivello, T. \& Rabinski, M. A. Morphometric analysis of the infraorbital foramen and accessories foraminas in Brazilian skulls. Int. J. Morphol., 22(4):273-8, 2004.

Hindy, A. M. \& Abdel-Raouf, F. A study of infraorbital foramen, canal and nerve in the adult Egyptians. Egypt. Dent. J., 39(4):573-80, 1993.

Hwang, K. \& Baik, S. H. Surgical anatomy of the orbit of Korean adults. J. Craniofac. Surg., 10(2):129-34, 1999.

Kazkayasi, M.; Ergin, A.; Ersoy, M.; Tekdemir, I. \& Elhan, A. Microscopic anatomy of the infraorbital canal, nerve, and foramen. Otolaryngol. Head Neck Surg., 129(6):6927, 2003.

Lee, U. Y.; Nam, S. H.; Han, S. H.; Choi, K. N. \& Kim, T. J. Morphological characteristics of the infraorbital foramen and infraorbital canal using three- dimensional models. Surg. Radiol. Anat., 28(2):115-20, 2006.

McKinstry, R. E. Transverse relationships of the infraorbital foramina in cleft and noncleft individuals. Am. J. Phys. Anthropol., 74(1):109-15, 1987.
Soper, R. T.; Pringle, K. C. \& Schefeild, J. C. The creation and repair of diaphragmatic hernia in foetal lambs: techniques and survival. J. Pediatr. Surg., 19:33-40, 1984.

Wolff, E. The bony orbit and accessory sinuses of the nerve. In: The anatomy of the eye and the orbit. $4^{\text {th }}$ ed. London, H.K. Lewis and Co. Ltd. 1954. pp.1-29.

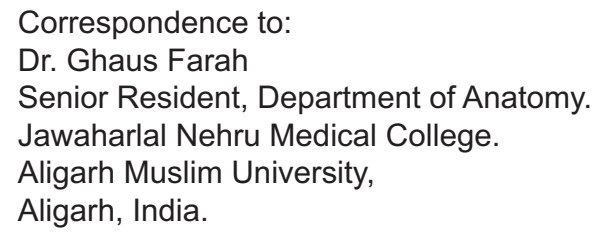

Telephone: + 91-9319201406 / 9411041594

Email: drfarahghaus@rediffmail.com drfarahghaus@gmail.com

Received: 28-07-2007

Accepted: 21-01-2008 